\title{
The Factors Which Influence the Level of Usage Success of HCIS (Human Capital Information System) (Case Study of BPJS Ketenagakerjaan)
}

\author{
Maulana Sidik, Dr. Elly Sapto Utomo
}

Gunadarma University, South Jakarta, Indonesia

\section{ABSTRACT}

HCIS (Human Capital Information System) is human resources management system at Badan Penyelenggara Jaminan Sosial (BPJS) Ketenagakerjaan (Labour Social Security Administration Agency). The purpose of implementing HCIS is to provide the best service for BPJS Ketenagakerjaan employees while the study of it was to analyze the success in using it with variables test such as system and information quality, perceived easy of use, perceived usefullness and user satisfaction by using the Structural Equation Model (SEM) analysis model. The samples were taken from 449 respondents and analytical tools used are The Measurement Validity Test (Absolute Fit Test, Fit Incremental Test) and Analysis the Indicators and Variables with AMOS (Analysis Moment of Structure) software. Based on the data analysis, the results show that all variables test has a positive effect on user satisfaction, and user satisfaction has a positive influence on usage success.

Keywords : BPJS Ketenagakerjaan, HCIS, SEM, Information System, Human Resource.

\section{INTRODUCTION}

As Social Security Administration Agency, BPJS Ketenagakerjaan has a mission to provide the best service for its customers. BPJS Ketenagakerjaan continues to improve competence across all service lines by developing various programs and benefits that can be perceived by cutomers and their families, especially in the service of filing claims. Furthermore, BPJS Ketenagakerjaan demanded to carry out various developments and improvements in all aspects with utilization of information technology, including the management of its human resources. The Department of Human Resource seeks to optimize the HR management system, therefore the availability of HCIS that are appropriate to the needs of the organization is an absolutely necessary part and also for accelerating strategic decision making for the Boards.
HCIS was designed to assist the Department of Human Resource in managing $\mathrm{HR}$ at BPJS Ketenagakerjaan with the following objectives:

1. Having a Competency Based Human Resource Management System (CBHRM) system in several moduls such as: Recruitment and Selection Modules, Personnel Modules, Training and Development, Performance Appraisal, Rewards Management, Talent Management, Career Management, Design and Evaluation Work, Payroll, and other matters related to HR business processes.

2. The system can accommodate administrative activities with other units related to business processes in the Human Resources Department and reduce repeated data input.

3. Has a reliable system, error tolerance and easy to use (user friendly). 


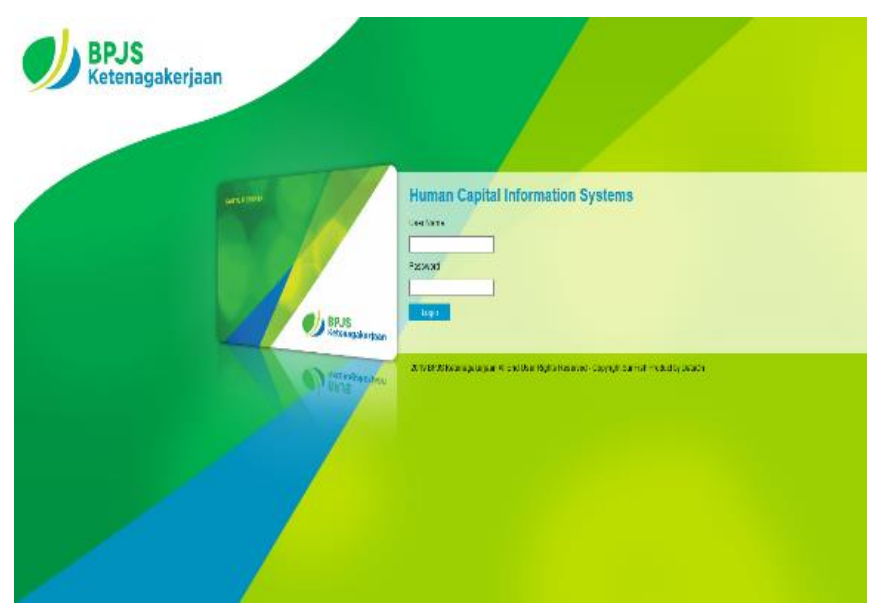

Figure 1. Human Capital Information System (HCIS)

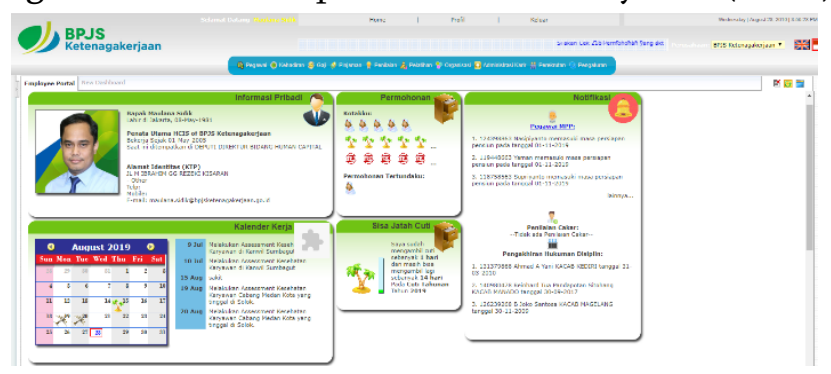

Figure 2. Home Window of HCIS

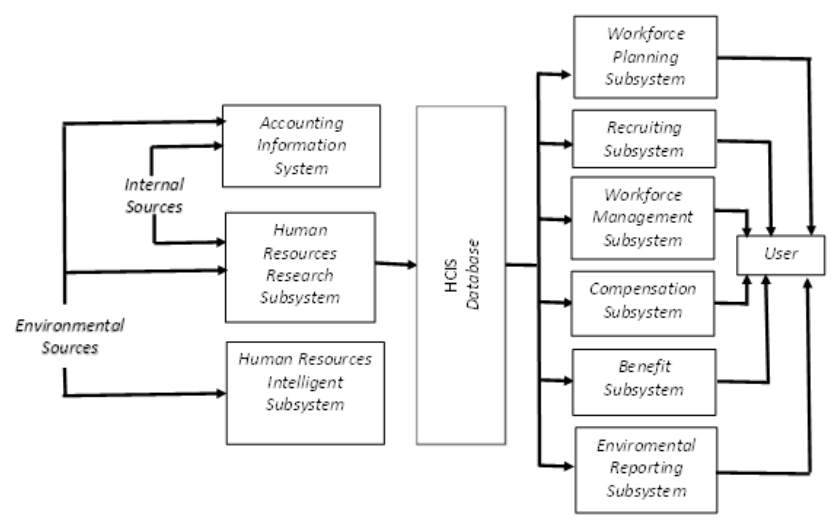

Figure 3. HCIS Flow

Based on it, the objectives of this study are as follows:

1. To analyze the influence of using HCIS in terms of system quality, information quality, perceived ease of use, perceived usefullness and user satisfaction.

2. To analyze user satisfaction on usage success of HCIS.

\section{RESEARCH METHODS}

The research method used is described in the following chart:

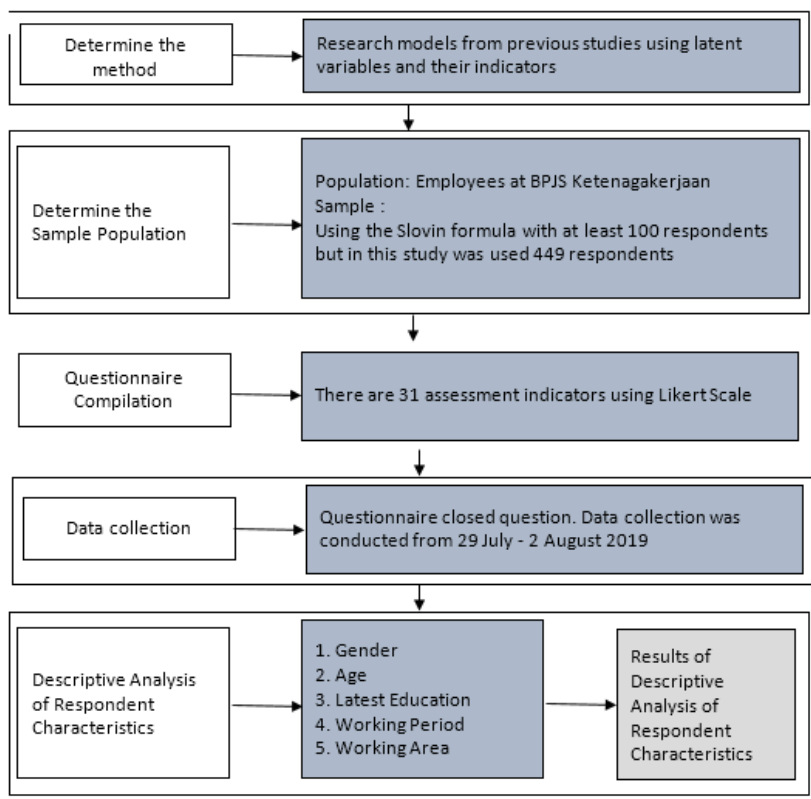

Chart 1. Research Method (1)

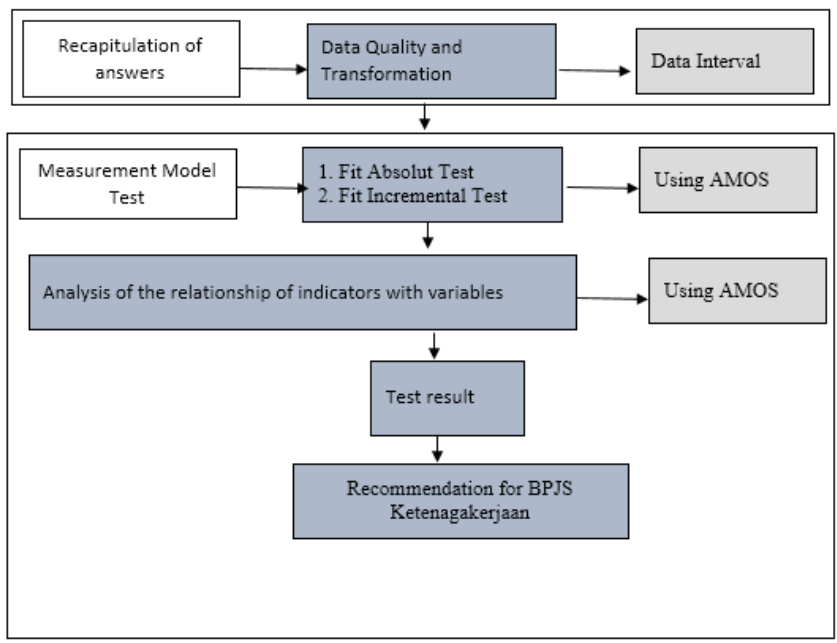

Chart 2. Research Method (2)

Sample of this study using The Slovin formula (Sujarweni, 2014) with a percentage error of $10 \%$. As sample obtained were 98.33 rounded up to 449 respondents from BPJS Ketenagakerjaan employees who used the HCIS until July 2019. As data collection techniques using primary data from distributing questionnaires to respondents and 
secondary data from literature and research books related. Variables used are system quality, information quality, ease of use, usability and user satisfaction which all include in total of 31 statement indicators.

Structural Equation Model (SEM) and AMOS (Analysis Moment of Structure) used as data analysis in this study. Data processed in descriptive analysis with only one variable and producing tables, graphs and diagrams (Sujarweni,2014).

Normality testing was carried out by looking at the criteria of the Skew critical value and the Kurtosis critical value on each indicator used (Hair, 2010). Critical value / critical ratio must be greater than 2.58 and not greater than +2.58 at a significant level of $1 \%$.

\section{Validity Test Measurement Model}

The Validity Measurement Model consists of:

\section{Absolute Fit Test}

Absolute fit test is used to measure the overall fit model (both structural models and joint measurement models) (Imam Ghozali 2004). The fundamental measure of overall fit is a high chisquare likelihood ratio relative to the degree of freedom indicating that the covariance matrix or correlation observed with the predicted is significantly different and this results in a probability (p) that is smaller than a significant level $(\alpha)$. Conversely, if a small chi square value will produce a probability value (p) that is greater than the significant level $(\alpha)$ and shows that the covariance matrix between predictions and observations is not significantly different.
The next test tool Goodness Of Fit Index (GFI), developed by Joreskog and Sorbom (1984) is a nonstatistical measure whose value ranges from 0 (poor fit) to 1.0 (perfect fit). A high GFI value indicates better fit and how much GFI is acceptable as a decent value there is no standard yet, but many researchers recommend values above $90 \%$ as a measure of good fit.

The test tool, Root Mean Square Error of Approximation (RMSEA), is a measure that tries to correct the tendency of chi-square to reject models with large sample sizes. RMSEA value between 0.05 to 0.08 that are acceptable size.

\section{Fit Incremental Test}

Fit Incremental Test is used to compare certain models with models that have the assumption that all indicators do not correlate with each other (null model). This test group is called the Baseline Comparisons. Test equipment used in this baseline comparison is Adjusted Goodness Fit of Index (AGFI), a development of GFI that has been adjusted to the ratio of degree of freedom. The recommended value is the same or $>0.900$. And next test tool is the Tucker Lewis Index (TLI), an incremental conformity index that compares the model tested with the baseline model. The recommended value is the same or $>0.900$. After, Normed Fit Index (NFI), a measure of comparison with the proposed model and the null model. The recommended value is the same or $>0.900$.

Finally, Comparative Fit Index (CFI), an incremental conformity index. This index is relatively insensitive to sample size and is less influenced by the complexity of the model. The recommended value is the same or $>0.900$. 
In convergent validity test will be tested if indeed an indicator explains a construct, then the indicator will have a high loading factor with that construct and the total indicator will have a high enough variance extracted. Factor loading above 0.5 indicates that an indicator is indeed part of the construct (Santoso, 2014). While the discriminant validity test will test if there are two or more constructs in one model, then each construct should have its own uniqueness and not related to other constructs. extracted variance above 0.5 can be a sign of adequate convergence (Santoso, 2014).

\section{DISCUSSION}

Descriptive Analysis of Respondent Characteristics

Characteristics of respondents who were sampled grouped to gender, age and education. The results of the questionnaire for Gender, the number of male respondents was 243 respondents or $54.12 \%$, while the number of female respondents was 206 respondents or $45.88 \%$. Age of respondents under 25 years as many as 33 respondents or $7.35 \%$, aged 25-34 years as many as 295 respondents or $65.70 \%$, aged 35-45 years as many as 77 respondents or $17.15 \%$, those aged 46-55 years were 40 respondents or $8.91 \%$ and aged over 55 years were 4 respondents or $0.89 \%$.

While the results of the questionnaire for education, the number of respondents educated the number of respondents who had a high school education were 3 respondents or $0.67 \%$, and respondents who had a Diploma education were 45 respondents or $10.02 \%$, the number of respondents educated with Bachelor Degree were 369 respondents or $82.18 \%$ and the number of respondents having Master Degree was 32 respondents or $7.13 \%$.

\begin{tabular}{|l|cccccc|} 
Variable & $\min$ & $\max$ & skew & \multicolumn{1}{c}{ c.r. } & kurtosis & c.r. \\
\hline SC1 & 1.000 & 5.315 & -.205 & -1.776 & -.411 & -1.780 \\
SC2 & 1.000 & 4.392 & -.071 & -.611 & -.557 & -2.411 \\
SC3 & 1.000 & 4.755 & -.070 & -.605 & -.504 & -2.181 \\
SC4 & 1.000 & 5.435 & -.146 & -1.260 & -.219 & -.947 \\
SC5 & 1.000 & 5.327 & -.112 & -.972 & -.165 & -.714 \\
SC6 & 1.000 & 5.284 & -.118 & -1.023 & -.206 & -.893 \\
PU4 & 1.000 & 4.569 & -.167 & -1.449 & -.361 & -1.560 \\
PU3 & 1.000 & 4.557 & -.163 & -1.414 & -.327 & -1.414 \\
PU2 & 1.000 & 4.496 & -.165 & -1.428 & -.438 & -1.893 \\
PU1 & 1.000 & 5.133 & -.159 & -1.373 & -.370 & -1.599 \\
PE U3 & 1.000 & 4.867 & -.253 & -2.192 & -.423 & -1.828 \\
PE U2 & 1.000 & 5.295 & -.166 & -1.438 & -.413 & -1.787 \\
PE U1 & 1.000 & 5.232 & -.283 & -2.444 & -.324 & -1.403 \\
IQ1 & 1.000 & 4.639 & -.157 & -1.362 & -.295 & -1.275 \\
IQ2 & 1.000 & 4.669 & -.246 & -2.129 & -.419 & -1.813 \\
IQ3 & 1.000 & 4.474 & -.152 & -1.317 & -.367 & -1.588
\end{tabular}

\begin{tabular}{|l|cccccc} 
Variable & $\min$ & $\mathbf{m a x}$ & skew & \multicolumn{1}{c}{ c.r. } & kurtosis & \multicolumn{1}{c}{ c.r. } \\
\hline IQ4 & 1.000 & 4.684 & -.165 & -1.429 & -.327 & -1.413 \\
IQ5 & 1.000 & 5.328 & -.195 & -1.691 & -.324 & -1.401 \\
IQ6 & 1.000 & 5.443 & -.164 & -1.421 & -.265 & -1.148 \\
IQ7 & 1.000 & 5.355 & -.214 & -1.849 & -.256 & -1.106 \\
IQ3 & 1.000 & 4.620 & -.194 & -1.674 & -.412 & -1.782 \\
IQ9 & 1.000 & 4.599 & -.172 & -1.491 & -.266 & -1.152 \\
IQ10 & 1.000 & 5.169 & -.163 & -1.411 & -.247 & -1.069 \\
US4 & 1.000 & 5.321 & -.197 & -1.706 & -.247 & -1.068 \\
US3 & 1.000 & 5.405 & -.156 & -1.350 & -.288 & -1.245 \\
US2 & 1.000 & 5.384 & -.203 & -1.758 & -.199 & -.863 \\
US1 & 1.000 & 5.282 & -.215 & -1.859 & -.336 & -1.453 \\
SQ1 & 1.000 & 4.732 & -.257 & -2.224 & -.522 & -2.259 \\
SQ2 & 1.000 & 5.342 & -.217 & -1.876 & -.403 & -1.745 \\
SQ3 & 1.000 & 4.421 & -.141 & -1.216 & -.503 & -2.175 \\
SQ4 & 1.000 & 4.698 & -.221 & -1.912 & -.507 & -2.191 \\
Multivariate & & & & & 389.097 & 91.138
\end{tabular}

Figure 4. Data Normality

(AMOS Output Results)

From the picture above, it can be seen that the critical ratio skewness value of all indicators shows a normal distribution because the value is greater than -2.58 or smaller than +2.58 while the multivariate normality test gives a value 91,138 well above the value of 2.58. so multivariate distribution is not normal.

\section{Bootstrapping}

Bootstrapping is a non-parametric method which the core of the technique is to enable researchers to produce large amounts of subsample from the original data (Byrne, 2009). The bootstrapping 
method uses sampling with the return of the original sample to get new samples. After sampling, the observations are returned again and the researcher can produce as many samples as desired without worrying about sample duplication unless it is accidental. Each sample was created and analyzed independently and the results will be compiled for the entire sample (Dachlan, 2014).

In this study, the authors used the Maximum Likelihood bootstrap method with a total subsample of 700 and 95 for the Bootstrap confidence level. The complete configuration can be seen in Figure 5 below. While the results of this bootstrapping are written in Figure 6.

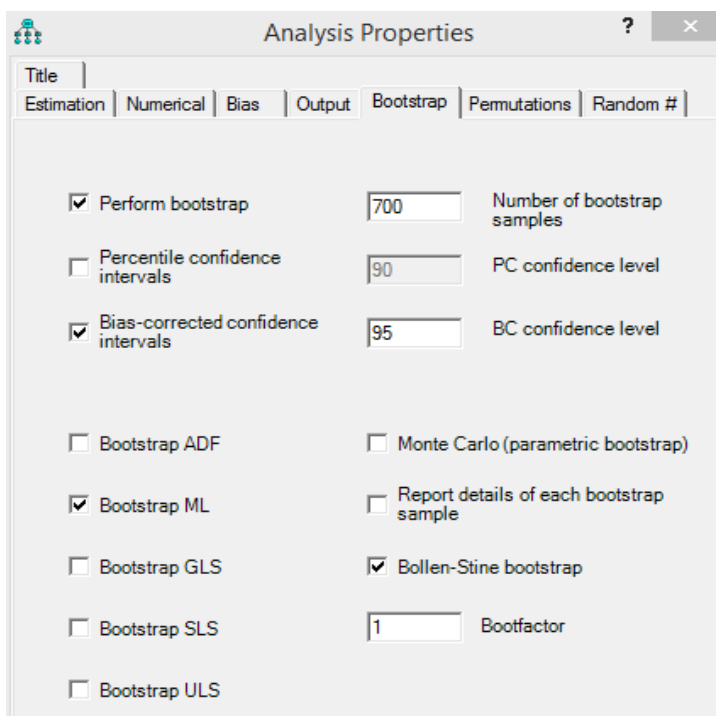

Figure 5 Bootstrapping settings

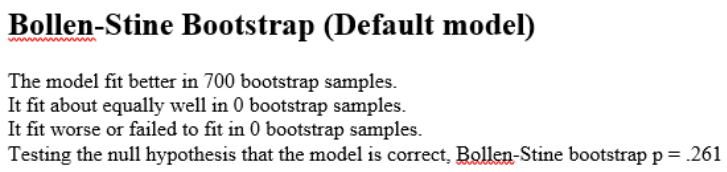

Testing the null hypothesis that the model is correct, Bollen-Stine bootstrap $p=.261$

Figure 6. Bootstrapping Output Results

In the original model without bootstrapping the value of chi-squares $=1020,493$ with probability $=$ 0,000 . while the Bollen-Stine bootstrap probability result $=0.261$ which states that the model cannot be rejected and this result is consistent with the results of the original chi-square model also does not reject the null hypothesis. With the bootstrapping output, the probability is 0.261 which mean the model is normal.

Test Model Measurement

Absolute Fit Test

Chi square. From figure 7 below was found that the value of chi square $=1020,493$ with $\mathrm{df}: 98$ and probability 0,000 . The chi square results show that the null hypothesis which states the same model with empirical data is rejected which means the model is not fit. However, chi square is very sensitive to the number of samples. The larger the sample, the more significant.

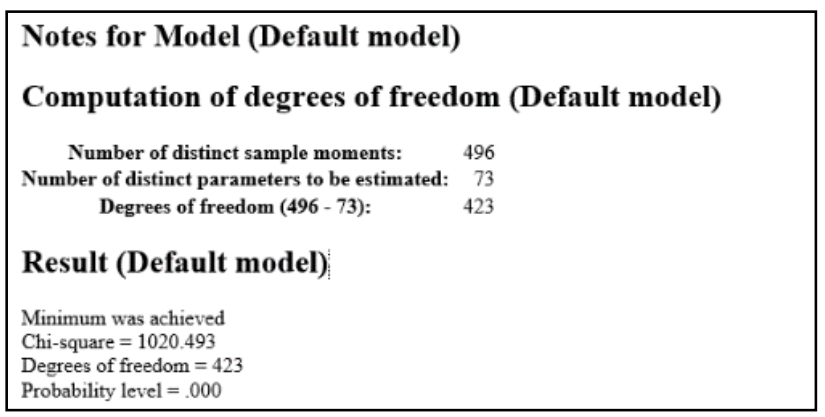

Figure 7. Notes for Model

(AMOS Output Results)

Goodness of Fit Index (GFI), a high GFI value indicates a better fit and how many GFI values can be accepted as a decent value there is no standard yet, but many researchers recommend values above $90 \%$ as a measure of good fit. From Figure 8 found that the value of GFI $=0.966$ where the value is above the condition of the fit criteria value is 0.900

\begin{tabular}{|l|crcc|}
\hline Model & RMR & GFI & AGFI PGFI \\
\hline Default model & .125 & .966 & .943 & .738 \\
Saturated model & .000 & 1.000 & & \\
Independence model & .515 & .072 & .010 & .068 \\
\hline
\end{tabular}

Figure 8. Results of GFI, RMR, AGFI and PGFI outputs 
Root Mean Square Error of Approximation (RMSEA), is a measure that tries to correct the chisquare tendency to reject models with large sample sizes. RMSEA value between 0.05 to 0.08 is an acceptable size that show in Figure 9 below.

\section{RMSEA}

\begin{tabular}{|l|cccc|}
\hline Model & \multicolumn{4}{|c|}{ RMSEA LO 90 HI 90 PCLOSE } \\
\hline Default model & .056 & .052 & .061 & .011 \\
Independence model & .270 & .266 & .274 & .000 \\
\hline
\end{tabular}

Figure 9. RMSEA Output Results

Incremental Test

Adjusted Goodness Fit of Index (AGFI), from Figure describe the value of AGFI $=0.943$ above while the fit criteria requirement is 0.900 . Tucker Lewis Index (TLI) is incremental conformity index that compares the tested model with the baseline model. From Figure 10 the TLI value $=0.957$ which above the condition of the fit criteria value is 0.900 .

\section{Baseline Comparisons}

\begin{tabular}{|l|ccccr|}
\hline Model & \multicolumn{1}{|c}{ NFI } & RFI & IFI & TLI & CFI \\
Deltal & rhol & Delta2 & rho2 & \\
\hline Default model & .935 & .928 & .961 & .957 & .961 \\
Saturated model & 1.000 & & 1.000 & & 1.000 \\
Independence model & .000 & .000 & .000 & .000 & .000 \\
\hline
\end{tabular}

Figure 10 Results of TLI, NFI, RFI, IFI and CFI outputs

Normed Fit Index (NFI) is a measure of comparison with proposed models and null models. From Figure 10 before, the value of NFI $=0.935$ which above the criteria fit value.

Comparative Fit Index (CFI) is incremental conformity index. This index is relatively insensitive to sample size and is less influenced by the complexity of the model. From Figure 10 before the value of CFI $=0.961$ wich still above the condition of the fit criteria value.

Analysis of the relationship of indicators and variables

After testing the measurement model and proven to be fit, then the next process will be carried out an analysis of the relationship of indicators with latent variables. This analysis is one of them using convergent validity test. The convergent validity test will see an indicator that the factor loading value must be high with the construct and the total indicator will have a high enough variance extracted. The loading factor must be $>0.50$ indicating that the indicator is indeed part of the construct (Santoso, 2014). Results of Regression Weight Output describe in following table. The Estimate column shows the value of the factor loading of each indicator against the construct variable.

\begin{tabular}{|c|c|c|c|c|c|c|}
\hline & & & Estimate & & & istimate \\
\hline SQ4 & $<--$ & SQ & 1.000 & IQ4 & $<---$ IQ & .975 \\
\hline SQ3 & $<-$ & SQ & .953 & & $<---\quad$ IQ & .917 \\
\hline SQ2 & $<-$ & SQ & .866 & & $<---$ IQ & .957 \\
\hline Q1 & $<-$ & SQ & & & $<---$ IQ & 932 \\
\hline $\mathrm{S} 1$ & $<-$ & US & & PEU 1 & $<---$ PEU & 1.000 \\
\hline 2 & $r=$ & & & PEU2 & $<--$ PEU & 1.068 \\
\hline & 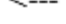 & & 95 & PEU3 & $<--$ PEU & 1.025 \\
\hline US3 & $<--$ & US & .993 & PU1 & $<--$ PU & 1.000 \\
\hline JS4 & $<--$ & US & .956 & $\begin{array}{l}\text { PU2 } \\
\text { PU3 }\end{array}$ & $\begin{array}{ll}<-- & P U \\
- & P U\end{array}$ & 1114 \\
\hline IQ10 & $<-$ & IQ & 1.000 & PU4 & $<--$ PU & 1.114 \\
\hline Q9 & $<-$ & IQ & .934 & $\mathrm{SC} 6$ & $<--$ SC & 1.000 \\
\hline IQ8 & $<-$ & IQ & .984 & $\mathrm{SC} 5$ & $<--$ SC & 1.023 \\
\hline IQ7 & $<--$ & IQ & 92 & $\mathrm{SC} 4$ & $<--$ SC & 1.035 \\
\hline IQ6 & $<-$ & IQ & .917 & $\mathrm{SC} 3$ & $<--$ & 039 \\
\hline Q5 & $<-$ & IQ & .879 & $\mathrm{SC} 1$ & $<--\quad S C$ & 1.004 \\
\hline
\end{tabular}

Figure 11 Results of Regression Weight Output

It show in Figure 11 of construct variable System Quality (SQ), the factor loading value of the indicators SQ1, SQ2, SQ3, and SQ4 sequently are $0.885,0.866,0.953$, and 1,000 which all above the standard value of $>0.5$, which mean all indicators have a strong relation with the construct variable System Quality(SQ). 
In Figure 11, factor loading values of indicators are above the standard value of $>0.5$, and thus indicators have a strong relation with the construct variable Information Quality (IQ).

The factor loading values of the PEU1, PUE2 and PEU3 indicators are: 1,000, 1,068, and 1,025 also above the standard value of $>0.5$, thus the indicators have a strong relation with the construct variable Perceived Ease of Use(PEU).

Also the construct variable Perceived Usefulness (PU), factor loading values of the indicators PU1, PU2, PU3, and PU4 are: 1,000, 1,054, 1,114, and 1,114 are above the standard values, which also have a strong relation with the construct variable Perceived Usefulness (PU).

For User Satisfaction (US) construct, the factor loading values of the indicators US1, US2, US3, and US4, sequently: $1,000,0.995,0.993$, and 0.956 are above the standard values of $>0.5$, and the Information System Success (SC) sequently: 1,004, 0,992, 1,039, 1,035, 1,023, and 1,000 which also above the standard values and all mean US and SC have strong relation with construct variable.

Based on the analysis of factor loading analysis on each indicator that is owned by latent variables in this study a total of 31 indicators all have a relationship to its construct variables.

Hypothesis Evaluation

Hypothesis testing is done by looking at the $\mathrm{P}$ value (probability) produced by IBM-Amos as shown in Figure 12 where the exogenous variable will affect the endogenous variable if the $\mathrm{P}$ value is 50.05 (Santoso, 2014). In addition, according to Hair et.al. (2010) it is mentioned that the influence of exogenous variables on endogenous variables can also be seen from the value of C.R (construct reliability) where if the value of C.R $\geq 0.7$ is included in the category of good reliability, where as if the value of C.R. between 0.6 and 0.7 is called marginal reliability and is still acceptable.

In the study all exogenous variables significantly influence User Satisfaction (US) include System Quality (SQ), Information Quality (IQ), Perceived Ease of Use (PEU), and Perceived Usefulness (PU). For variables that influence the Information System Success (SC) are User Satisfaction (US). Evaluation results can be seen in table below.

\begin{tabular}{|c|c|c|c|c|c|}
\hline & Estimate & S.E. & C.R. & $\mathbf{P}$ & Label \\
\hline US <--- $\quad$ SQ & .311 & .083 & 9.128 & **** & \\
\hline US <--- IQ & .615 & .082 & 7.528 & *** & \\
\hline US <--- PEU & .484 & .061 & 8.384 & **** & \\
\hline US <--- $\quad$ PU & .346 & .036 & 9.642 & *** & \\
\hline $\mathrm{SC}<---\quad$ US & 873 & .040 & 21.600 & **** & \\
\hline
\end{tabular}

Figure 12. Regression Weight Output Results

The hypothesis for context of the usage success of HCIS are:

1. System Quality has a positive effect on User Satisfaction (H1).

2. Information Quality has a positive effect on User Satisfaction (H2)

3. Perceived Ease of Use term has a positive effect on User Satisfaction (H3).

4. Perceived Usefulness term has a positive effect on User Satisfaction (H4).

5. User Satisfaction has a positive effect on Information System Success (H5). 


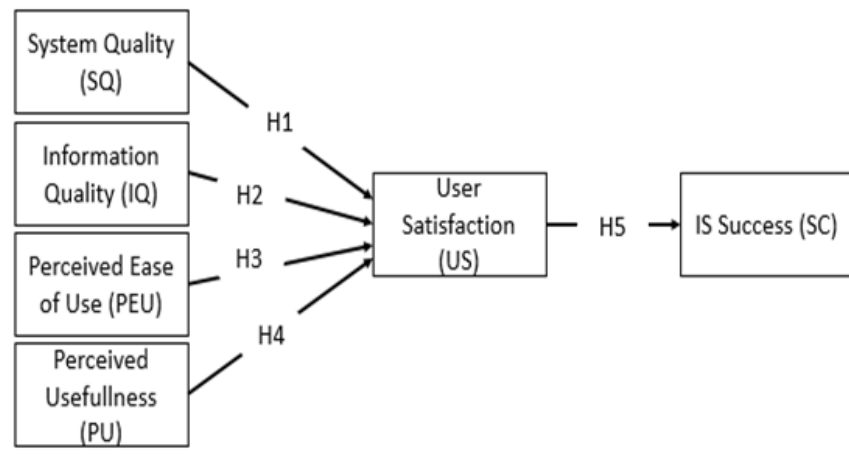

Figure 13 Hypothesis

\section{CONCLUSION}

Based on the results of the analysis of research, the conclusion regarding the factors that influence the usage success of HCIS are as follows:

1. The results of data analysis from the research data are fully fit and successful with the proposed model.

2. System Quality Variables, Information Quality, Perceived Ease of Use and Perceived Usefullness that have a positive effect on User Satisfaction on HCIS.

3. The User Satisfaction variable has a positive effect on the success of using HCIS.

4. Factors that influence usage success of HCIS: System Quality, Information Quality, Perceived Ease of Use, Perceived Usefullness and User Satisfaction .

\section{REFERENCES}

[1]. Al Shibly, H. (2011). Human Resource Information Systems Success Assessment: An Integrative Model. Australian Journal of Basic and Apllied Sciences, 157-169.

[2]. BPJS Ketenagakerjaan. (2018). Strategi Human Capital BPJS Ketenagakerjaan 2018-2021. Jakarta: BPJS Ketenagakerjaan.
[3]. Dachlan, U. (2014). Panduan Lengkap Structural Equation Modelling. Semarang: Lentera Ilmu.

[4]. Davarpanah, A., \& Mohamed, N. (2013). Human Resource Information Systems (HRIS) Success Factors In A Public Higher Education Institution Context. Internetional Conference on Research and Innovation in Information Systems, 79- 84 .

[5]. DeLone, W. H., \& McLean, E. R. (2003). The DeLone and McLean Model of Information System Success : A Ten-Year Update. Journal of Management Information Systems, Vol. 19, No. 4, pp 9-30.

[6]. Ghozali Imam (2004). Model Persamaan Struktural Konsep \& Aplikasi Dengan Program AMOS 19.0 Semarang Badan Penerbit Universitas Diponegoro.

[7]. Hair, J., Black, W. C., Babin, B. J., \& Anderson, R. E. (2010). Multivariate Data Analysis Seventh Edition. Pearson Prentice Hall.

[8]. Hancock, G. R., \& Mueller, R. O. (2013). Structural Equation Modeling A Second Course. Charlotte: Information Age Publishing .

[9]. Hendrickson, A. (2003 ). Human Resource Informastion System: Backbone Technology of Contemporary Human Resources. Journal of Labor Research Vol XXIV, Number 3.

[10]. Kline, R. B. (2011). Principles and Practice of Structural Equation Modeling Third Edition. London: The Guilford Press.

[11]. McHaney, R., Hightower, R., \& Pearson, J. (2002). A Validation of the End User Computing Satisfaction Instrument in Taiwan. Information and Management, 503-511.

[12]. McLeod, R. (2001). Management Information Systems Eighth Edition. New Jersey: Prentice Hall.

[13]. McLeod, R., \& Anctis, G. (1995). A ResourceFlow Model of the Human Resource 
Information System. Information Technology Management.

[14]. Rai, A., Lang, S. S., \& Welker, R. B. (2002). Assesing the Validity of IS Success Model: An Empirical Test and Theoretical Analysis. Information System Research, 50-69.

[15]. Rainer, R. K., \& Cegielski, C. G. (2012). Introduction to Information Systems 4th Edition. International Student Version.

[16]. Santoso, S. (2014). Konsep Dasar dan Aplikasi SEM dengan Amos 22. Jakarta: PT Elex Media Komputindo.

[17]. Silver, Lynne, M., Beath, M. M., \& Mathis. (1995). The Information Technology Interaction Model: A Foundation for the MBA Core Course. Minneapolis: MIS Research Center.

[18]. Sugiyono. (2013). Metode Penelitian Pendidikan Pendekatan Kuantitaif, Kualitatif, dan R\&D. Bandung: Alfabeta Bandung.

[19]. Ulrich, D. (197). Human Resource Champion : The Next Agenda for Adding Value and Delivering Result. Harvard Bussiness School Press, 473-490.

[20]. Venkatesh, V., Morris, M., Davis , G., \& Davis, F. (2003). User Acceptance of Information Technology: Toward a Unified View. MIS Quarterly, 425-478.

[21]. Winkler, S., Konig, C. J., \& Kleinmann, M. (2013). What Makes Human Rsource Information System Successful? Managers' Perception of Attributes for Successful Human Resource Information. The International Journal of Human Resource Management Vol.24, 227-242.
Cite this article as :

Maulana Sidik, Dr. Elly Sapto Utomo, "The Factors Which Influence the Level of Usage Success of HCIS (Human Capital Information System) (Case Study of BPJS Ketenagakerjaan) ", International Journal of Scientific Research in Science and Technology (IJSRST), Online ISSN : 2395-602X, Print ISSN : 2395-6011, Volume 6 Issue 4, pp. 309-317, JulyAugust 2019. Available at doi : https://doi.org/10.32628/IJSRST196459 Journal URL : http://ijsrst.com/IJSRST196459 